\title{
NONPARAMETRIC METHODS IN THE ANALYSIS OF THE QUALITY OF KERNEL OF SELECTED WINTER WHEAT CULTIVARS
}

\author{
Magdalena Ćwiklińska ${ }^{\mathrm{a}^{*}}$, Zofia Hanusz ${ }^{\mathrm{b}}$, Jakub Soja $^{\mathrm{c}}$, Renata Polak ${ }^{\mathrm{d}}$ \\ a Department of Applied Mathematics and Computer Science, University of Life Sciences in Lublin, \\ Poland, e-mail: magdalena.cwiklinska@up.lublin.pl, ORCID 0000-0001-7497-7314 \\ b Department of Applied Mathematics and Computer Science, University of Life Sciences in Lublin, \\ Poland, e-mail: zofia.hanusz@up.lublin.pl, ORCID 0000-0002-0757-554X \\ c Department of Thermal Technology and Food Process Engineering, University of Life \\ Sciences in Lublin, Poland, e-mail: jakubsoja97@wp.pl \\ d Department of Thermal Technology and Food Process Engineering, University of Life Sciences in \\ Lublin, Poland, e-mail: renata.polak@ up.lublin.pl, ORCID 0000-0001-5880-566X \\ *Corresponding author: e-mail: magdalena.cwiklinska@up.lublin.pl
}

\begin{tabular}{ll}
\hline ARTICLE INFO & ABSTRACT \\
\cline { 2 - 2 } $\begin{array}{l}\text { Article history: } \\
\text { Received: July } 2021\end{array}$ & $\begin{array}{l}\text { The paper presents a statistical analysis of weight and diameter of ker- } \\
\text { neceived in the revised form: } \\
\text { nugust } 2021\end{array}$ \\
$\begin{array}{l}\text { Accepted: September } 2021 \\
\text { analyses of experimental results, such as compliance with a normal dis- } \\
\text { tribution, equality of variance for particular cultivars, and occurrence of } \\
\text { nonparametric methods, } \\
\text { winter wheat, } \\
\text { seed quality }\end{array}$ & $\begin{array}{l}\text { outliers proved that there is no justification for the use of a traditional } \\
\text { one-way analysis of variance for verification of hypotheses according } \\
\text { to which weight and diameter of grains of the investigated winter wheat } \\
\text { cultivars do not differ. A nonparametric Kruskal-Wallis test was used } \\
\text { for verification of hypotheses which based on the experimental results } \\
\text { enabled to reject both hypotheses. Further, simultaneous average } \\
\text { weight and diameters of grain of the investigated cultivars were com- } \\
\text { pared with the use of Nemenyi-Dunn test. The applied test enabled to } \\
\text { conclude which cultivars had a significantly higher weight than the oth- } \\
\text { ers. Analogous comparisons were carried out for the diameter of kernels } \\
\text { of the investigated winter wheat cultivars. }\end{array}$ \\
\hline
\end{tabular}

\section{Introduction}

The wheat quality is assessed based on technological properties and even more often based on physical properties. The studies that monitor the physical features of kernel aim at unification of these properties which may have a significant impact on the effectiveness of technological processes of food products manufacture. Unification of the weight and size of kernels increased the effectiveness of grinding (Geodecki and Grundas, 2003). A great variability of the properties within the same cultivar justifies the need to measure a great number of kernels (Dziki et al., 2011). The size and uniformity of kernel influence many processes such as screening, dehusking or grinding and constitute quality markers of kernel (Dziki et 
al., 2011). The size of kernel influences the bulk density, PSI hardness index and ash content. (Dziki and Laskowski, 2004). In practice, in the statistical analysis of experimental results with a big number of iterations, traditional assumptions such as normality or homogeneity (uniformity) of variance are not always met. Traditional methods such as analysis of variance should not be used then.

\section{Material and methods}

Experimental results come from the Department of Thermal Technology of Process Engineering of the University of Life Sciences in Lublin. The studies concerned a comparison of physical and technological properties of a kernel of eight cultivars of winter wheat. Wheat kernels came from the collection located in Lubelskie Voivodeship. A computer system of single kernels characteristics called Single Kernel Characterization system (SKCS) type 4100 by Perten Instruments for investigation of wheat kernels was used. The analyzer is useful for assessment of unification of the mass and size of kernel and enables control of humidity of grain before milling (Dziki et al., 2011). $30 \mathrm{~g}$ - samples of grain of each cultivar were poured into a device. During one measurement cycle including 300 grains, randomly selected kernels were weighted (mg). Then, for each grain, a substitute diameter was determined which approximately corresponds to the grain thickness $(\mathrm{mm})$, water content $(\%)$ and grain hardness index HI (wheat hardness index) expressed in unitless units. Determination of kernel parameters with SKCS is a final test since as a result, the kernel structure is destroyed (Grundas, 2004). The paper presents the statistical analysis of experimental results of kernel properties of the selected winter wheat cultivars. Weight and substitute diameter (diameter) of kernels of the selected cultivars of winter wheat were analysed. Descriptive statistics was computed, and results were illustrated with histograms and box diagrams. Further, the test of normal distribution of samples and uniformity of variance for the investigated cultivars was performed. A nonparametric analysis of variance was used for investigation of the weight and diameters of kernels of the tested cultivars. The statistical analysis was performed at the level of significance of 0.05 with the use of a free statistical software R (https://www.r-project.org).

Procedures available in the programming language and $\mathrm{R}$ environment were used for statistical analysis of weight and diameter of kernels. These were respectively shapiro.test (in stats packet), leveneTest (in car packet) and kruskal (in agricolae packet) (de Mendiburu 2021). The basic information on the programming language and $R$ environment may be found in the paper by Biecek (2008).

\section{Results of statistical analysis}

The basic descriptive statistics of the weigth and diameter obtained for three hundred kernels of eight investigated cultivars of winter wheat marked by o_1, o_2, to o_8 was listed in Table 1.

Descriptive statistics for weight and diameter presented in table 1 inform us on location and distribution of the obtained weights and diameters of kernels for the investigated cultivars. For each cultivar one may notice slight differences between medians and average values which may suggest absence of distribution for the investigated cultivars. It may be also easily 
Nonparametric Methods...

noticed that distributions (Max-Min) and standard deviations for the weight and diameter of kernels for particular cultivars differ, which may indicate that the objectives on the equality of variance for particular cultivars may not be met. Therefore, it may appear that samples for the weight and diameter of kernels of the investigated winter wheat cultivars do not come from a population with a normal distribution and thus a classic method of the analysis of variance cannot be applied.

Table 1.

Basic descriptive characteristics for weight and diameter of kernels in eight cultivars of winter wheat

\begin{tabular}{|c|c|c|c|c|c|c|c|c|}
\hline \multirow{2}{*}{$\begin{array}{l}\text { Prop- } \\
\text { erty }\end{array}$} & \multirow{2}{*}{ Cultivar } & \multirow{2}{*}{ Min } & \multirow{2}{*}{ Max } & \multicolumn{3}{|c|}{ Quartiles } & \multirow{2}{*}{$\begin{array}{l}\text { Aver- } \\
\text { age }\end{array}$} & \multirow{2}{*}{$\begin{array}{l}\text { Standard } \\
\text { deviation }\end{array}$} \\
\hline & & & & Lower & Median & Upper & & \\
\hline \multirow{8}{*}{ 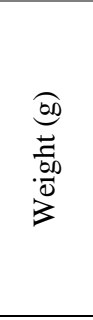 } & o_1 & 16.90 & 79.35 & 35.53 & 40.88 & 46.92 & 41.34 & 8.15 \\
\hline & o_2 & 12.76 & 71.76 & 33.12 & 37.26 & 41.05 & 37.30 & 6.22 \\
\hline & o_3 & 20.70 & 67.96 & 32.77 & 36.57 & 41.40 & 37.25 & 6.53 \\
\hline & o_4 & 20.01 & 76.93 & 35.88 & 41.05 & 45.88 & 40.62 & 7.49 \\
\hline & o_5 & 21.04 & 76.24 & 31.39 & 35.53 & 40.02 & 36.40 & 7.67 \\
\hline & o_6 & 13.45 & 60.03 & 32.00 & 35.02 & 38.38 & 35.35 & 5.66 \\
\hline & o_7 & 19.66 & 57.61 & 35.19 & 39.67 & 43.47 & 39.40 & 6.50 \\
\hline & o_8 & 21.73 & 67.62 & 33.12 & 36.57 & 39.67 & 36.83 & 5.55 \\
\hline \multirow{8}{*}{ 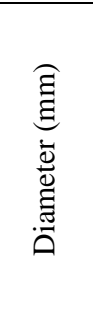 } & o_1 & 2.30 & 4.11 & 2.81 & 2.97 & 3.23 & 3.04 & 0.33 \\
\hline & o_2 & 1.90 & 3.90 & 2.77 & 2.93 & 3.12 & 2.96 & 0.26 \\
\hline & o_3 & 2.09 & 3.86 & 2.72 & 2.88 & 3.05 & 2.91 & 0.28 \\
\hline & o_4 & 2.27 & 4.05 & 2.91 & 3.09 & 3.28 & 3.10 & 0.30 \\
\hline & o_5 & 2.25 & 3.92 & 2.72 & 2.89 & 3.05 & 2.90 & 0.26 \\
\hline & o_6 & 2.10 & 4.09 & 2.71 & 2.82 & 3.00 & 2.86 & 0.24 \\
\hline & o_7 & 2.10 & 3.87 & 2.77 & 2.93 & 3.13 & 2.97 & 0.29 \\
\hline & o_8 & 2.23 & 4.05 & 2.73 & 2.87 & 3.04 & 2.91 & 0.27 \\
\hline
\end{tabular}

Histograms with adjusted diagrams of the density function of the normal distribution presented in Fig. 1 and 2 were performed for the initial assessment of the distribution of the weight and diameter of the investigated cultivars of winter wheat. One may notice that density functions of the normal distribution are quite well suited to the distribution of weight and diameter of kernels almost for all cultivars. Only for the weight of o_5 cultivar and o_8 cultivar kernels, they indicate some sharpening of the weight distribution. On the other hand, in case of a diameter of kernels one may notice sharpening of the distribution for cultivar o_1, o_3, o_6 and o_8. Descriptive statistics in table 1 and histograms only suggest no normal distribution. Therefore, normality of the investigated properties for particular cultivars and uniformity of variance must be always checked with suitable tests. 


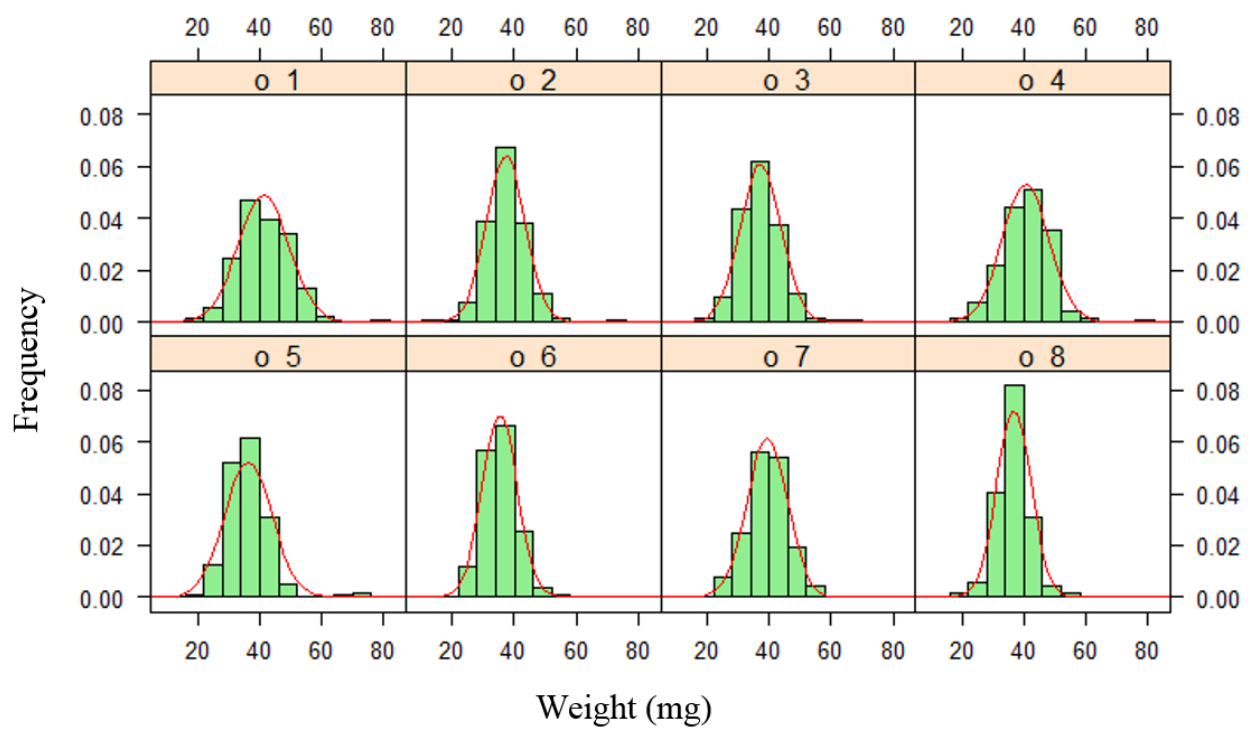

Figure 1. Histograms for the weight of kernels for the investigated eight cultivars of wheat

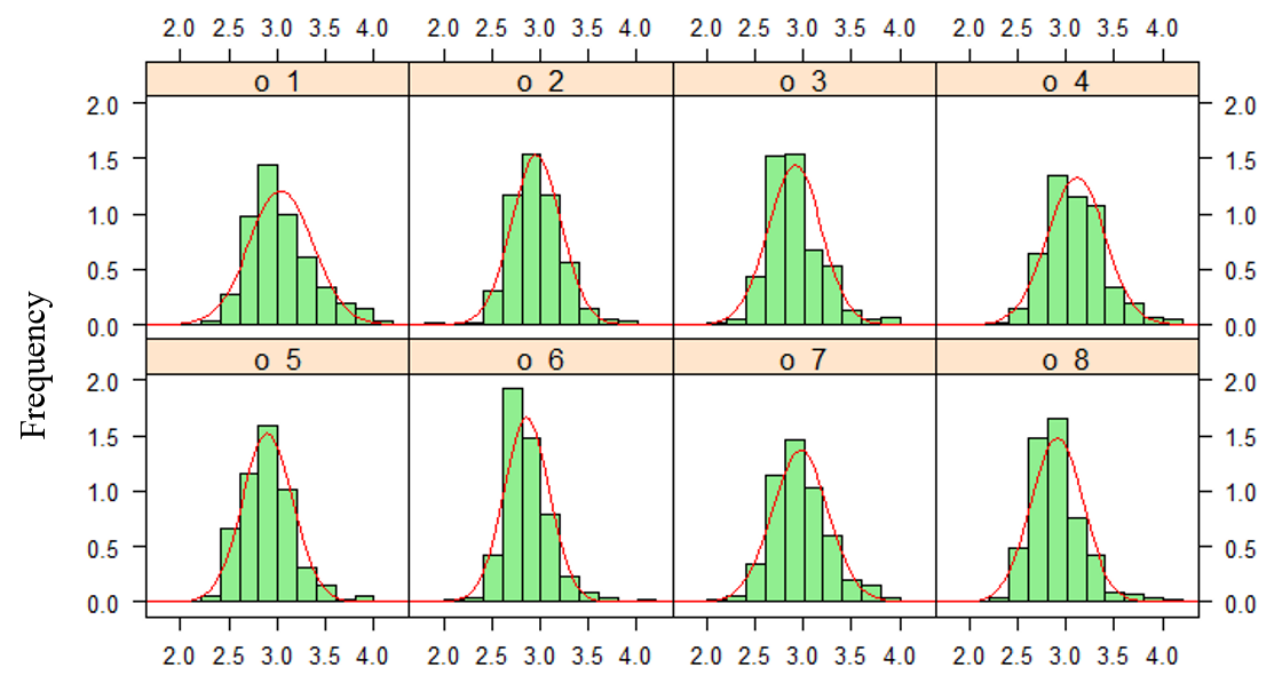

Diameter $(\mathrm{mm})$

Figure 2. Histograms for the diameter of kernels for the investigated eight cultivars of wheat

Shapiro-Wilk test was used for verification of hypotheses on the compliance of weight and diameter of kernels distribution, which is a recommended test for investigation of normality (Thode, 2002; Koronacki and Mielniczuk, 2001; Srivastava, 2003; Górecki, 2011). 
Nonparametric Methods...

The results of the obtained p-values for the Shapiro-Wilk test value for the experimental results of weight and diameter of kernels of the investigated cultivars were set in Table 2 .

Table 2 .

P-values of Shapiro-Wilk test for the weight and diameter of kernel of the investigated cultivars

\begin{tabular}{lcc}
\hline Cultivar & Weight & Diameter \\
\hline o_1 & 0.0096 & $<0.0001$ \\
o_2 & $<0.0001$ & 0.0003 \\
o_3 & 0.0002 & $<0.0001$ \\
o_4 & 0.0006 & 0.0012 \\
o_5 & $<0.0001$ & $<0.0001$ \\
o_6 & 0.0007 & $<0.0001$ \\
o_7 & $\mathbf{0 . 9 5 7 5}$ & 0.0002 \\
o_8 & $<0.0001$ & $<0.0001$ \\
\hline
\end{tabular}

It may be easily noticed that the distribution of the weight of kernels from cultivar o_7 may be found compliant with the normal distribution since $\mathrm{p}=0.9575$ (thickened number) is higher than the one accepted at the level of significance 0.05 . All the remaining p-values are considerably lower than the level 0.05 , which proves that the experimental results clearly indicate that hypotheses on the compliance with the normal distribution of the weight distribution and diameter of kernel of the investigated cultivars of winter wheat are rejected.

In practice, for large number of samples it is assumed that even if the assumption of the normality of distribution is not met, then classic statistical methods are used, since F Snedecor test (Fisher) in the analysis of variance is resistant to departure from normality (Lovric, 2011). Nonetheless, one should also check the assumption on the uniformity of variance in compared groups which is also a basic assumption of the analysis of variance (Koronacki and Mielniczuk, 2001).

Thus, hypotheses on the uniformity of variance were also verified, namely a verification of the assumption that variations of weight and diameter of kernels for eight investigated cultivars of winter wheat are the same in the compared groups. For this purpose, BrownForsyth test was performed (which is a modification of Levene's test) whose values are calculated based on medians. Values of test functions and corresponding p-values obtained for the analysed experimental results are shown in Table 3

Table 3.

$P$-values of Brown and Forsyth test for uniformity of variance for the weight and diameter of kernel of eight cultivars of winter wheat

\begin{tabular}{lccc}
\hline Property & Value of Brown-Forsyth & Degrees of freedom & p-value \\
\hline Weight & 9.85 & 7 & $<0.0001$ \\
Diameter & 5.57 & 7 & $<0.0001$ \\
\hline
\end{tabular}

P-values in table 3 indicate unambiguously that hypotheses on the uniformity of variance both for weight and diameter of the investigated eight cultivars of winter wheat should be 
rejected. Thus, another assumption of the classic analysis of variance was not met. According to the source literature (Lovric, 2011; Koronacki and Mielniczuk, 2001), analysis of variance is resistant to slight derogations from the normality of distribution and to small differences between the variances if the number in the group does not differ.

Whereas, the analysis of variance is not resistant to outliers (Koronacki and Mielniczuk, 2001). To find out whether the analysed properties of kernels include outliers, box diagrams presented in Figure 3 were created. The bottom and upper basis of boxes constitute respectively a bottom and upper quartile. It should be mentioned that outliers are higher than $\mathrm{Q} 3+1,5(\mathrm{Q} 3-\mathrm{Q} 1)$ or lower than $\mathrm{Q} 1-1,5(\mathrm{Q} 3-\mathrm{Q} 1)$, where $\mathrm{Q} 1$ and $\mathrm{Q} 3$ mean respectively the bottom and upper quartile.
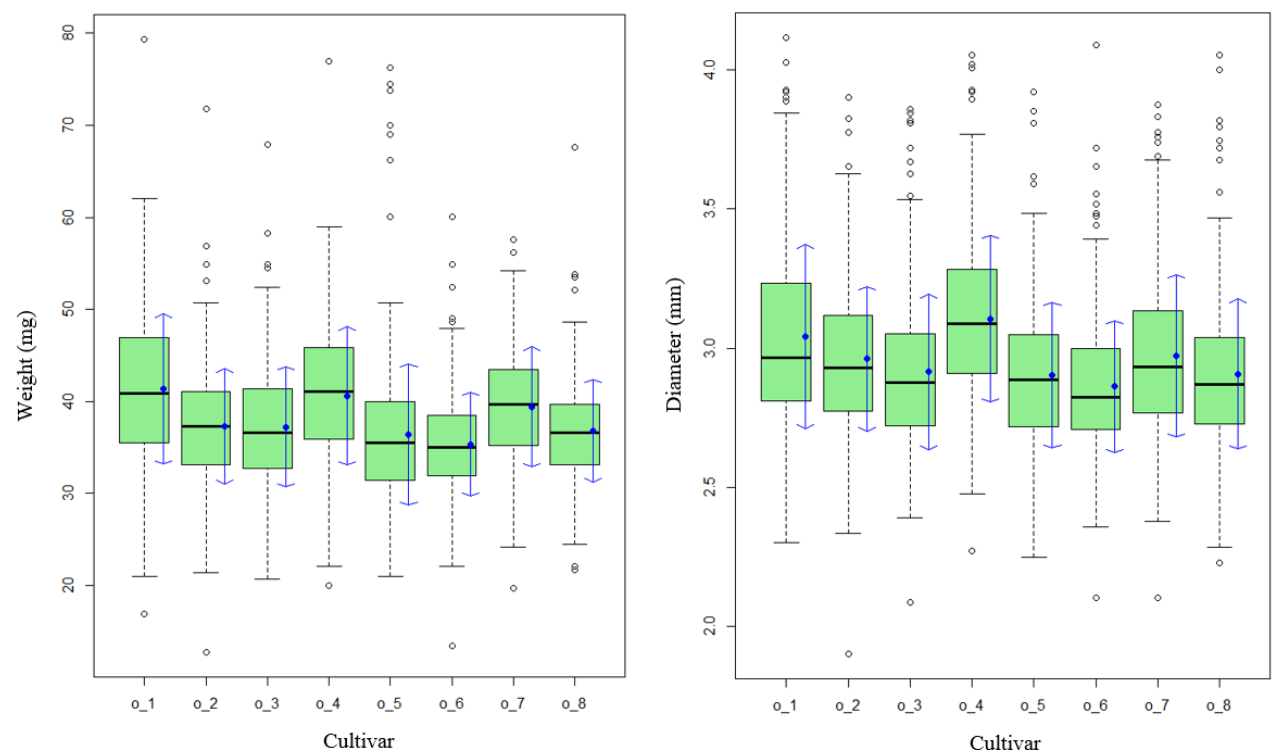

Figure 3. Box diagrams for weight and diameter of kernels for the investigated eight cultivars of wheat and the averages marked with dots and ranges +/- standard deviation in the form of arrows

It may be easily noticed that outliers (marked with symbol $\circ$ ) occurred, which consequently influences the average values and standard deviations.

Taking into consideration that assumptions on the compliance with normal distribution and on the uniformity of variance for weight and diameter of kernels of the investigated cultivars were not met and additionally outliers occurred, it is justifiable to use nonparametric methods for further statistical analyses. Main hypotheses which we would like to verify are hypotheses that the average weight and diameters of kernels of the investigated eight cultivars of winter wheat are the same. These hypotheses in nonparametric methods decide whether medians for the weight and diameter of kernels for the investigated cultivars are the same. 
Nonparametric Methods...

These hypotheses may be thus presented in the form of:

and

$$
H_{\text {weight }}^{0}: M e_{\text {weight_o_1 }}=M e_{\text {weight_o_2 }}=\cdots=M e_{\text {weight_o_8 }}
$$

$$
H_{\text {diameter }}^{0}: M e_{\text {diameter_o_1 }}=M e_{\text {diameter_o_2 }}=\cdots=M e_{\text {diameter_o_8 }} \text {. }
$$

Kruskal-Wallis test was applied for testing the above zero hypotheses on the equality of medians for the weight of kernels and medians for the diameter of kernels of eight investigated wheat cultivars. It is equivalent to F Snedecor test in one-way analysis of variance. It should be emphasised that nonparametric Kruskal-Wallis test is based on ranks which are used to replace the experimental results. The obtained results of Kruskal-Wallis test and pvalues for the above hypotheses were presented in table 4.

Table 4.

The results of Kruskal-Wallis test for the hypothesis on the equality of medians obtained for the mass and diameter of kernels of the investigated eight cultivars of winter wheat

\begin{tabular}{lccc}
\hline Property & Test value & Degrees of freedom & p-value \\
\hline Mass & 210.13 & 7 & $<0,0001$ \\
Diameter & 165.40 & 7 & $<0.0001$ \\
\hline
\end{tabular}

The obtained p-values placed in table 4 indicate that zero hypotheses are rejected. Therefore, we may conclude that both medians for the weight of kernels and medians for the diameter of kernels for some of the eight investigated cultivars of winter wheat differ significantly ( $p$-values are considerably lower than the assumed level of significance 0.05 ). Since the hypotheses on the equality of medians for mass and medians for diameter of grains of the investigated cultivars of winter wheat were rejected, further it should be investigated which cultivars significantly vary the investigated properties.

Therefore, for simultaneous comparisons Nemenyi-Dunn test, also called Dunn test was applied for this purpose. The average ranks for mass and diameter of kernels were presented in Table 5 and Table 6. Moreover, at the average ranks, letter symbols were introduced that indicate which cultivars differ significantly at the level of significance 0.05 .

Table 5 .

Results of simultaneous comparisons for mass (various letters prove the significant difference)

\begin{tabular}{cc}
\hline Cultivar & $\begin{array}{c}\text { Average } \\
\text { ranks for mass }\end{array}$ \\
\hline o_1 & $1497.95 \mathrm{a}$ \\
o_4 & $1476.85 \mathrm{a}$ \\
o_7 & $1368.51 \mathrm{~b}$ \\
o_2 & $1141.11 \mathrm{c}$ \\
o_3 & $1118.05 \mathrm{c}$ \\
o_8 & $1083.18 \mathrm{~cd}$ \\
o_5 & $995.42 \mathrm{de}$ \\
o_6 & $922.94 \mathrm{e}$ \\
\hline
\end{tabular}


Table 6.

Results of simultaneous comparisons for diameter (various letters prove a significant difference)

\begin{tabular}{cc}
\hline Cultivar & $\begin{array}{c}\text { Average } \\
\text { ranks for the diameter }\end{array}$ \\
\hline o_4 & $1562.21 \mathrm{a}$ \\
o_1 & $1362.60 \mathrm{~b}$ \\
o_7 & $1244.43 \mathrm{c}$ \\
o_2 & $1243.29 \mathrm{c}$ \\
o_3 & $1087.76 \mathrm{~d}$ \\
o_5 & $1080.88 \mathrm{~d}$ \\
o_8 & $1063.07 \mathrm{de}$ \\
o_6 & $959.77 \mathrm{e}$ \\
\hline
\end{tabular}

Based on the results presented in Table 5 one may state that the highest average of ranks for the kernels weight was observed for cultivars o_1 and o_4. These ranks are significantly higher than ranks for the mass of kernels of the remaining cultivars. The lowest average rank of kernel mass was obtained for cultivars o_6 and o_5. On the other hand, in case of the diameter of kernels, the highest average rank was in case of o_4 cultivar kernels, whereas the lowest kernels from cultivar o_6 and o_8. It should be mentioned that comparison of ranks of the investigated properties transfers clearly to comparison of medians for these properties.

The order of ordering average ranks listed in table 5 and 6 for the mass and diameter of kernels should be identified with the order of central location measures. Therefore, based on these tables one may make conclusions concerning differences between average values of the investigated properties for these cultivars.

Division of cultivars into uniform groups based on the letter symbols in table 5 and table 6 were illustrated in figures 4 and 5 .

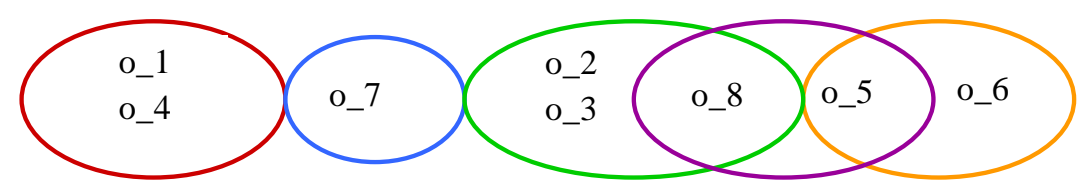

Figure 4. Diagram illustrating results of simultaneous comparisons for the mass of kernels

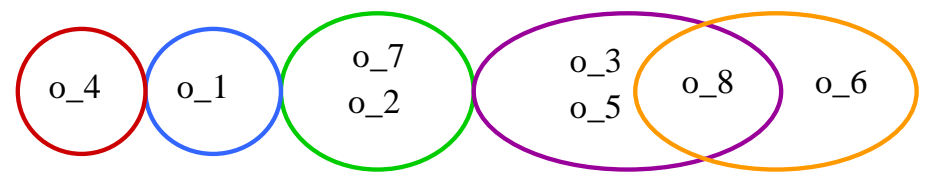

Figure 5. Diagram that illustrates results of simultaneous comparisons for diameter of kernels 
Nonparametric Methods...

It may be easily noticed that kernels of cultivars o_1 and o_ 4 are characterised on the average by the highest weight and diameter which significantly distinguish them from kernels of the remaining cultivars with regard to these properties. Whereas there is no one cultivar with the considerably lowest mass and diameter of kernel.

\section{Conclusion}

The paper presents the nonparametric statistical analysis which enabled a statistical conclusion concerning comparison of the agreed eight cultivars of winter wheat. For each cultivar, weight, and diameter of 300 grains was measured. The performed initial statistical analysis suggested no basis for the application of $\mathrm{F}$ Snedecor test in the classical analysis of variance. At the assumed level of significance 0.05 it was explained that for all cultivars the distribution of mass and diameter of kernels was not compliant with the normal distribution, except for the distribution of the mass of o_7 cultivar. Experimental results have not also confirmed homogeneity of variance for weight and diameter of particular cultivars. Moreover, occurrence of outliers was reported for all cultivars. Thus, nonparametric Kruskal-Wallis test which enabled rejection of the investigated hypotheses was used for verification of zero hypotheses on the uniform average mass of kernels and uniform average diameters of kernels of eight tested cultivars of winter wheat. Nemeyi-Dunn test was used for further detailed analysis. It enabled to decide for which cultivars, ranks for kernel mass are significantly higher than the ranks of masses of the remaining cultivars. Analogous detailed comparisons were carried out for the diameter of grains of the investigated cultivars of winter wheat. It was concluded that kernels of the first and fourth cultivar were of the highest mass. The applied statistical mass of the obtained experimental results from SKCS device may be helpful for identification and classification of wheat grain with regard to the quality, both as a sowing material and one for processing.

\section{References}

Biecek, P. (2008). Przewodnik po pakiecie R. Oficyna Wydawnicza GiS. Wrocław. ISBN: 978-8362780-22-8

De Mendiburu, F. (2021). Statistical Procedures for Agricultural Research, Package 'Agricolae', https://cran.r-project.org/web/packages/agricolae/agricolae.pdf [available 15.09.2021].

Dziki, D., Laskowski, J. (2004). Influence of kernel size on grinding process of wheat at respective grinding stages. Polish Journal of Food and Nutrition Sciences, 54(1), 29-33.

Dziki, D., Różyło, R., Laskowski, J., Grundas, S. (2011). Ocena właściwości fizycznych ziarna pszenicy przy wykorzystaniu analizatora pojedynczych ziarniaków. Inżynieria rolnicza 1(126), 39-46.

Fox, J., Weisberg, S. (2019). An R Companion to Applied Regression, Third edition. Sage, Thousand Oaks CA. https://socialsciences.mcmaster.ca/jfox/Books/Companion/ [available 15.09.2021]

Geodecki, M., Grundas S. (2003). Liczba i masa ziarniaków w kłosku i kłosie pszenicy, Acta Agrophysica, 2(4), 743-748.

Górecki, T. (2011). Podstawy statystyki z przykładami $w$ R. Wydawnictwo BTC, Legionowo. ISBN: 978-83-60233-69-6.

Grundas, S (2002). Monitoring jednorodności ziarna zbóż - propozycje rozwiązań aparaturowych dla celów hodowlanych i przemysłowych. Biuletyn Informacyjny PAN, 7, 708. 
Grundas, S. (2004). Charakterystyka właściwości fizycznych ziarniaków w kłosach pszenicy zwyczajnej Triticum aestivum L., Acta Agrophysica, 102. http://www.old.acta-agrophysica.org/artykuly/acta_agrophysica/ActaAgr_102_2004_0_0_0.pdf. [available 15.09.2021].

Koronacki, J., Mielniczuk, J. (2001). Statystyka dla studentów kierunków technicznych i przyrodniczych. Wydawnictwa Naukowo-Techniczne, Warszawa. ISBN: 9788301199784

Lovric, M. (red.) (2011): International Encyklopedia of Statistical Science. Springer, ISBN 978-3-64204898-2;

Srivastava, M.S. (2003). Methods of Multivariate Statistics, John Wiley \& Sons, New York. ISBN: 978-0-471-46172-2

Thode, H.C. (2002). Testing for Normality, Marcel Dekker, Inc. New York. ISBN 9780429213250.

\section{ZASTOSOWANIE METOD NIEPARAMETRYCZNYCH W ANALIZIE JAKOŚCI ZIARNA WYBRANYCH ODMIAN PSZENICY OZIMEJ}

Streszczenie. W pracy przedstawiono analizę statystyczną masy oraz średnicy ziarniaków uzyskanych dla ośmiu badanych odmian pszenicy ozimej. Wstępne analizy wyników eksperymentalnych, takie jak, zgodność z rozkładem normalnym, równość wariancji dla poszczególnych odmian oraz wystąpienie obserwacji odstających, wykazały brak podstaw do zastosowania klasycznej jednokierunkowej analizy wariancji do weryfikacji hipotez o braku zróżnicowania masy oraz średnicy ziarniaków badanych odmian pszenicy ozimej. Do weryfikacji hipotez wykorzystano nieparametryczny test Kruskala-Wallisa, który w oparciu o wyniki eksperymentalne pozwolił odrzucić obydwie hipotezy. W dalszej kolejności dokonano porównań jednoczesnych średnich mas i średnic ziarniaków badanych odmian stosując test Nemenyi-Dunna. Zastosowany test pozwolił stwierdzić, które odmiany charakteryzowały się masą istotnie wyższą od pozostałych. Analogiczne porównania przeprowadzono dla średnicy ziarniaków badanych odmian pszenicy ozimej.

Słowa kluczowe: metody nieparametryczne, pszenica ozima, jakość ziarna 